\title{
Surgical management of Favre-Racouchot syndrome
}

\author{
Charalambos Skoulakis MD ${ }^{1}$, Andreas Manios MD ${ }^{2}$, Theognosia Chimona MD ${ }^{1}$, Dimitrios Tsiftsis $\mathrm{MD}^{2}$ \\ Departments of ${ }^{l}$ Otolaryngology and ${ }^{2}$ Surgical Oncology, University Hospital of Crete \\ (School of Medicine), Crete, Greece
}

\section{Skoulakis, A Manios, T Chimona, D Tsiftsis. Surgical management of Favre-Racouchot syndrome. Can J Plast Surg 2001;9(3):91-93.}

BACKGROUND: Nodular elastosis of the skin or Favre-Racouchot syndrome presents as thick yellow plaques with cysts and comedones around the periorbital area in people with prolonged exposure to ultraviolet radiation.

OBJECTIVE: To demonstrate the surgical management of Favre-Racouchot syndrome.

METHODS: Surgical excision of affected skin in a 55-year-old farmer with Favre-Racouchot syndrome and reconstruction of skin defects by using a local flap and a free graft were performed.

RESULTS: Skin lesions were successfully excised with an acceptable aesthetic result, and the patient's condition was excellent two years after the removal.

CONCLUSION: Surgical treatment for Favre-Racouchot syndrome is recommended when there are extensive lesions by using either local flaps or free grafts.

Key Words: Actinic keratosis; Favre-Racouchot syndrome; Nodular elastosis; Surgical treatment; Therapeutic management

\section{Traitement chirurgical de la maladie de Favre et Racouchot}

CONTEXTE : L'élastéïdose nodulaire ou la maladie de Favre et Racouchot se manifeste sous la forme de plaques jaunes, épaisses, accompagnées de kystes et de comédons sis dans la région périorbitaire chez les personnes ayant subi une exposition prolongée aux rayons ultraviolets.

OBJECTIF : Présenter le traitement chirurgical de la maladie de Favre et Racouchot.

MÉTHODE : Excision chirurgicale de la peau lésée chez un fermier de 55 ans atteint de la maladie de Favre et Racouchot et reconstruction de la perte de substance cutanée au moyen d'un lambeau prélevé localement et d'un greffon libre.

RÉSULTATS : L'intervention a permis l'excision complète des lésions cutanées et a donné des résultats acceptables sur le plan de l'esthétique. L'état du patient était excellent deux ans après l'opération.

CONCLUSION : Le traitement chirurgical de la maladie de Favre et Racouchot, au moyen de lambeaux locaux et de greffons libres, est recommandée dans les cas de lésions étendues.

A ctinic lesions of the skin may become apparent during the third decade of life or later. In disorders such as xeroderma pigmentosum, lesions appear early, even in childhood (1). Heredity, prolonged sun exposure and the action of several chemical factors, promote the development of lesions (2).
One manifestation of sun-damaged skin is actinic elastosis. When lesions are located on the neck, the disorder is known as Farmer's neck or cutis rhomboidalis nuchae. When the upper extremities are affected, the disorder is known as actinic comedonal plaques or solar elastotic bands (3). When the ear is affected, it is known as nodular chondrodermatitis,

Correspondence: Dr Theognosia Chimona, Kounavi Pediados, 70100 Heraklion, Crete, Greece. Telephone +30 81741715 , fax +30 945 432145, e-mailivlat@tee.gr 


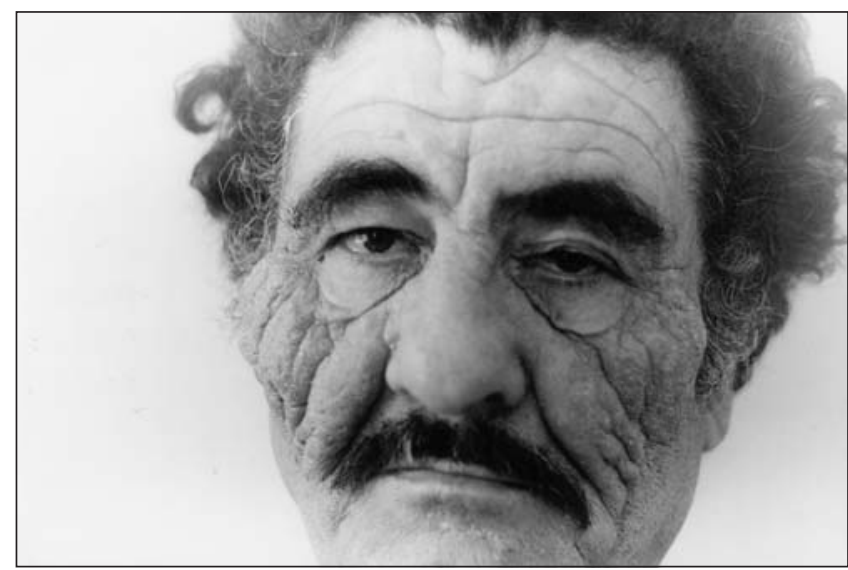

Figure 1) Frontal view of large nodular masses of malar area bilateral before surgery

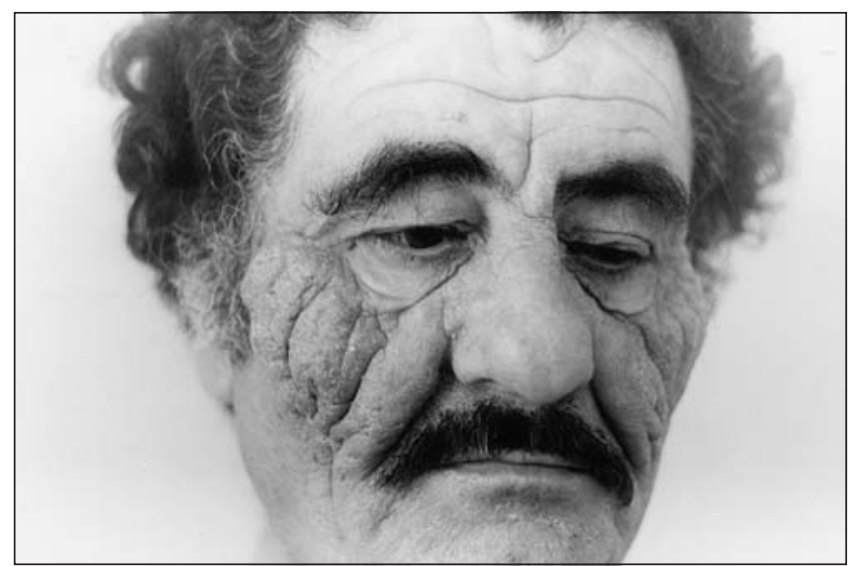

Figure 2) Right oblique view before surgery

and when the facial region (cheek or periorbital area) is affected, the disorder is termed 'Favre-Racouchot syndrome'.

The underlying biochemical mechanism of the syndrome is not well known. The main abnormality is rapid reproduction of the elastic fibres of the skin with the concurrent development of cysts and comedones that characterize the disorder.

\section{CASE PRESENTATION}

A 55-year-old farmer presented with skin lesions of five years' duration, involving both of his cheeks. The lesions were characterized by deep furrows, comedones and yellowish nodules, and progressively increased in size. They were suppurated often and fetid, and had deformed the features of the patient's face (Figures 1,2). There were no similar lesions on any other part of the patient's body. History and physical examination did not reveal other serious disorders.

The patient, being a farmer, had prolonged sun exposure and reported that for a long time he was also exposed to coal tar.

Treatment with oral antibiotics and ointments or the removal of cysts offered only temporary relief, and the patient's condition progressively worsened.

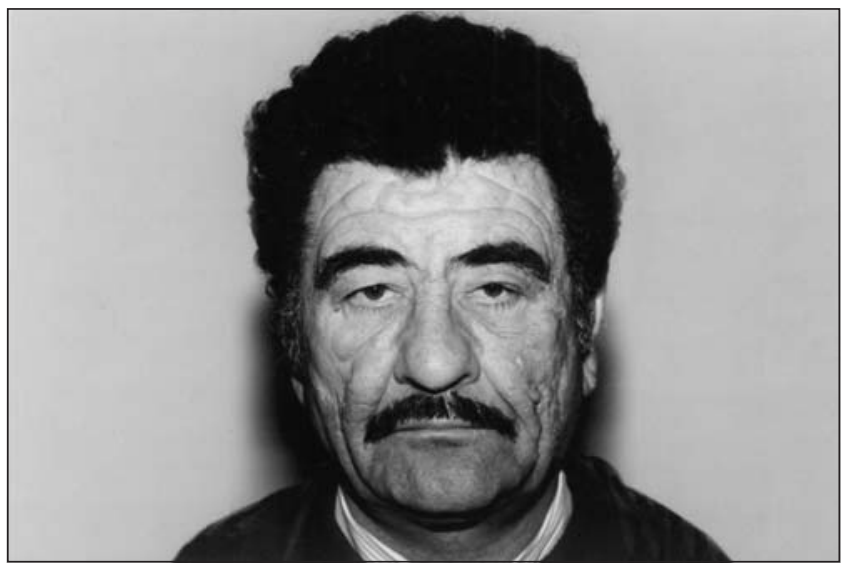

Figure 3) Frontal view six months after surgery

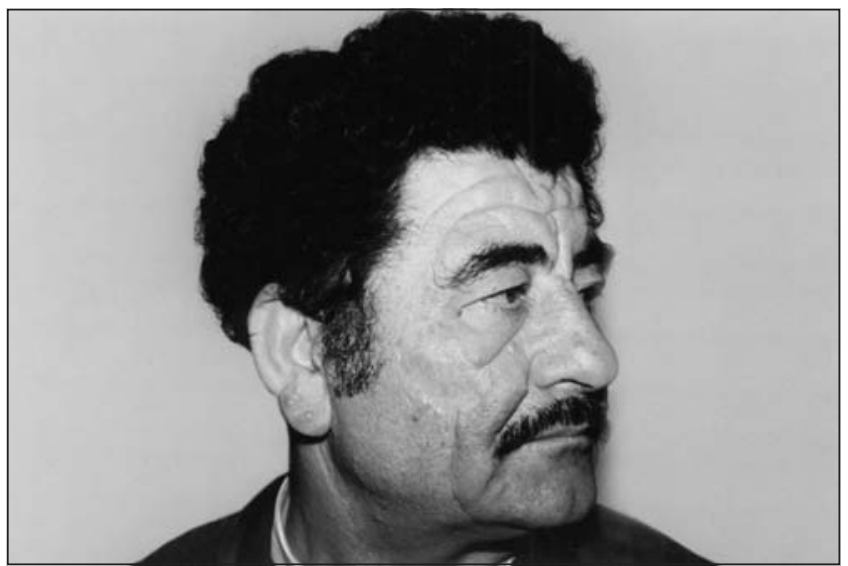

Figure 4) Right oblique view six months after surgery

Because the lesions were extensive, surgical treatment of the affected areas was undertaken. Under general anesthesia, the lesions were excised extensively and the defects were repaired. Reconstruction of the left cheek was performed with a local flap, while on the right cheek, where the defect was larger, a free skin graft was used. The depth of the lesions was remarkable, as was the profuse purulent discharge and the fetor of the area.

Multiple cultures of the pus developed Escherichia coli, and the histological examination revealed a thinned epidermis with keratin-filled cysts and elastotic degeneration of dermal collagen.

After surgery the patient took antibiotic therapy for 10 days due to the $E$ coli. Six months later, the aesthetic result was excellent (Figures 3,4).

\section{DISCUSSION}

Favre-Racouchot syndrome occurs mainly in people with a history of chronic sun exposure. Exposure to cold temperatures, chemical factors and radiation therapy have also been reported to be risk factors for the development of the disorder (4). In the present case report, the patient had 
prolonged sun exposure; however, his contact with tar coal was also significant.

The diagnosis of Favre-Racouchot syndrome is based on clinical examination and histological data. The differential diagnosis includes skin cancer and actinic keratosis. FavreRacouchot syndrome is estimated to occur in approximately $6 \%$ of individuals older than the age of 50 years, and is found predominantly in men (4).

The therapeutic approach used depends on the extent of lesions. The use of retinoic acid $(0.05 \%)$, applied at night, has been shown to be useful in loosening large comedones and facilitating manual comedo extraction when used three to four weeks before the procedure (5).

Dermabrasion produces some improvement (6) but also leaves some changes in the appearance of the skin in the affected area; simple extraction of the lesions, however, is usually followed by a recurrence of them $(7,8)$.

Tretinoin in alcohol solution is effective, but twice-daily applications are required for nine to 16 weeks to achieve beneficial treatment results (8).

Another therapeutic approach is the use of a $2 \mathrm{~mm}$ curette for eradicating individual comedones and cysts (8).

In advanced cases, the treatment is surgical excision of the lesions; however, surgery is difficult because of the extensive skin involvement and the deep adhesions to the underlying tissues. Complications include facial nerve injury and post- operative ectropion. Sometimes, it is difficult to cover an extensive skin defect with local flaps; however, a free skin graft may be used with success.

In the present case, the skin defect on the patient's right cheek was $5 \quad 7 \mathrm{~cm}$ and the defect on the left cheek was $45 \mathrm{~cm}$. On the left cheek, the defect was covered by using an Esser flap; however, for the defect on the right cheek, a supraclavicular skin graft was performed.

\section{REFERENCES}

1. Van Steeg H, Kraemer KH. Xeroderma pigmentosum and the role of UV-induced DNA damage in skin cancer. Mol Med Today 1999;5:86-94.

2. Calderone DC, Fenske NA. The clinical spectrum of actinic elastosis. J Am Acad Dermatol 1995;32:1016-24.

3. John SM, Hamm H. Actinic comedonal plaque - a rare ectopic form of the Favre-Racouchot syndrome. Clin Exp Dermatol 1993;18:256-8.

4. Friedman SJ, Su WP. Favre-Racouchot syndrome associated with radiation therapy. Cutis 1983;31:306-10.

5. Thomas JR III, Doyle JA. The therapeutic uses of topical vitamin A acid. J Am Acad Dermatol 1981;4:505.

6. English CPT, David T, Martin MAJ, George C, Reisner COL, John E. Dermabrasion for nodular cutaneous elastosis with cysts and comedones. Arch Dermatol 1971;104:92-4.

7. Plewig G. Dermabrasion for nodular cutaneous elastosis with cysts and comedones. Arch Dermatol 1972;105:294-6.

8. Mohs FE, McCall MW, Greenway HT. Curettage for removal of the comedones and cysts of the Favre-Racouchot syndrome. Arch Dermatol 1982;118:365-6. 